\title{
Contamination of Dog Feed by Fumonisins
}

\author{
Erika Mitsuo Kiyoko Teixeira (I), Michele Frehse (II), Roberta Lemos \\ Freire (II), Melissa Tiemi Hirozawa (I), Jaqueline Gozzi Bordini (I), \\ Mario Augusto Ono (III), Elisa Yoko Hirooka (IV), Elisabete Yurie \\ Sataque Ono (I)
}

(I) UEL - Universidade Estadual de Londrina (Departamento de Bioquímica e Biotecnologia, Caixa Postal 10.011, 86057-970), (II) UEL - Universidade Estadual de Londrina (Departamento de Medicina Veterinária Preventiva, Caixa Postal 10.011, 86057-970), (III) UEL - Universidade

Estadual de Londrina (Departamento de Ciências Patológicas, Caixa Postal 10.011, 86057970), (IV) UEL - Universidade Estadual de Londrina (Departamento de Ciência e Tecnologia de Alimentos Caixa Postal 10.011, 86057-970)

\section{Resumo}

Cereal grains used in feed production are often contaminated with toxic secondary metabolites produced by filamentous fungi (mycotoxins). Fumonisins are a group of mycotoxins produced mainly by Fusarium verticillioides and $\mathrm{F}$. proliferatum. Although several analogues have been identified and characterized, fumonisin $\mathrm{B}_{1}\left(\mathrm{FB}_{1}, \mathrm{FB}_{2}\right.$, and $\mathrm{FB}_{3}$ occur at significant levels in naturally contaminated corn and corn-based products. Fumonisins in feed are associated with toxic effects such as interference with cell membrane metabolism, inhibition of sphingolipid metabolism and damage of several organs. The aim of this study was to evaluate the contamination of dog feed by fumonisins in Northern Paraná State, Brazil. Natural occurrence of fumonisins was evaluated in three feed types (Standard, Premium and Super Premium) intended for dogs ( $\mathrm{n}=81$ ), collected from the residence of the owners. Fumonisins were determined by a reverse-phase isocratic HPLC system, using methanol: $0.1 \mathrm{M} \mathrm{NaH}_{2} \mathrm{PO}_{4}$ (80:20, v/v) adjusted to $\mathrm{pH} 3.3$ as mobile phase. $\mathrm{FB}_{1}$ and $\mathrm{FB}_{2}$ were detected in $72.8 \%$ and $51.9 \%$ of feed samples with levels ranging from 31.3 to 303.7 $\mu \mathrm{g} / \mathrm{kg}$ and 36.1 to $972.2 \mu \mathrm{g} / \mathrm{kg}$, respectively. Fumonisins $\left(\mathrm{FB}_{1}+\mathrm{FB}_{2}\right)$ were detected in $77.6 \%, 72 \%$ and $42.9 \%$ of Standard, Premium and Super

\footnotetext{
Referência:

Erika Mitsuo Kiyoko Teixeira, Michele Frehse, Roberta Lemos Freire, Melissa Tiemi Hirozawa, Jaqueline Gozzi Bordini, Mario Augusto Ono, Elisa Yoko Hirooka, Elisabete Yurie Sataque Ono.Contamination of Dog Feed by Fumonisins. In: Anais do $12^{\circ}$ Congresso Latinoamericano de Microbiologia e Higiene de Alimentos - MICROAL 2014 [= Blucher Food Science Proceedings, num.1, vol.1]. São Paulo: Editora Blucher, 2014. DOI 10.5151/foodsci-microal-063
} 
Premium feed, respectively. Most feed samples (66.7\%) showed fumonisin $\left(\mathrm{FB}_{1}+\mathrm{FB}_{2}\right)$ levels below $450 \mu \mathrm{g} / \mathrm{kg}$. Mean FBs $\left(\mathrm{FB}_{1}+\mathrm{FB}_{2}\right)$ levels were $272.43 \mu \mathrm{g} / \mathrm{kg}$ (Standard), $78.22 \mu \mathrm{g} / \mathrm{kg}$ (Premium), and $186.53 \mu \mathrm{g} / \mathrm{kg}$ (Super Premium). There was no significant difference in mean fumonisin levels among all the dog feed types by the Kruskal-Wallis test ( $p>0.05$ ). In spite of the maximum allowed levels for fumonisins $\left(\mathrm{FB}_{1}+\mathrm{FB}_{2}\right)$ have not been established for pet food, the maximum levels detected $(1014.72 \mu \mathrm{g} / \mathrm{kg})$ were below the maximum tolerable limit $(4000 \mu \mathrm{g} / \mathrm{kg})$ recommended by the Brazilian Association of Pet Products Industry (2013). The estimated mean fumonisin daily intake $(1.479 \mu \mathrm{g} / \mathrm{kg}$ bw/day) for dogs was below the acceptable daily intake ( $20 \mu \mathrm{g} / \mathrm{kg}$ body weight/day) and the pet safe dietary level $(2000 \mu \mathrm{g} / \mathrm{kg}$ dog feed), indicating that all the feed samples were considered safe for dogs concerning fumonisins. Despite the low levels of contamination observed in this study, more studies are necessary to evaluate the chronic effects of fumonisins on dog health.

Palavras-Chave: Dog feed, fumonisins, mycotoxins

Agência de Fomento: CNPq (the Brazilian Government organization for grant aid and fellowship to Brazilian researchers) in association with MAPA ( Ministry of Agriculture, Livestock and Food Supply), the Araucária Foundation, Paraná Fund/SETI and CAPES 